\title{
RISK MANAGEMENT \\ IN FUTURE ROMANIAN E-GOVERNMENT 2.0 PROJECTS
}

\section{Didraga Otniel, $\mathbf{P h D}$}

West University of Timisoara

Email: otniel.didraga@e-uvt.ro

(Received June 2015; accepted August 2015)

\begin{abstract}
E-government public services in Romania must follow unitary procedures considering the new requirements of the European Union from the Digital Agenda for Europe Strategy 2020. E-government 2.0 has to be implemented because of the cultural and behavioral transformations in the interaction between governments and users of e-services. E-government 2.0 projects use tools and techniques of social media to accomplish their goals. This article examines the possible risk categories and the risk management procedures needed to mitigate risks in future Romanian e-government projects, according to the strategic lines of development for the Digital Agenda. We propose a risk management plan for the e-government lines of action within the strategic lines of development that includes identifying, assessing, and mitigating the risks. New and modernized government services through e-government 2.0 projects that apply risk management will bring a significant improvement in how citizens and businesses relate to government and will increase the use of e-government services.
\end{abstract}

Keywords: E-government 2.0, E-government projects, Risks, Risk Management, Romania J.E.L. CODES: H7, H11, D81.

\section{Introduction}

The recently published document in February 2015 by the Ministry for Information Society (MCSI, 2015) refers to the National Strategy on Digital Agenda for Romania. It is aligned and tailored according to the Digital Agenda for Europe for the 2014-2020 period. The first field of action - "eGovernment, Interoperability, Cyber Security, Cloud Computing, Open Data, Big Data and Social Media" is mapped on the following Digital Agenda for Europe Pillars: Pillar I - Digital Single Market, Pillar II - Interoperability \& Standards, Pillar V - Research and Innovation, Pillar VI - Enhancing digital literacy, skills and inclusion, and Pillar VII - ICT-Enabled benefits for EU Society (MCSI, 2015). All the future egovernment 2.0 projects must comply with the strategic lines of development and fit the lines of action in the National Strategy on Digital Agenda for Romania (MCSI, 2015). The objective of this article is to examine the possible risk categories within future e-government 2.0 projects and to propose a risk management plan and procedures needed for the success of the projects. As there are no risk management procedures mentioned in the strategic lines of development 
Didraga, O., (2015)

Risk management in future romanian e-government 2.0 projects

and the lines of action specifically for e-government, we propose a risk awareness culture for future e-government 2.0 projects. The potential risks of e-government 2.0 projects are manageable, and the mitigation approaches must consider the involvement of citizens, businesses, and other public authorities because of the emergence of Web 2.0 technologies and the ascent of social networks (Boughzala et al., 2015).

\section{Literature review}

E-government means using ICT by the local or central public administration to provide better, cheaper and faster services for citizens, businesses or other public administration organizations (European Commission, 2014). E-government was introduced in the mid/late 1990s (Boughzala et al., 2015). Most researchers discuss models of e-government after the year 2000 (Bannister and Connolly, 2015).

\subsection{E-government in Romania}

In Romania, before the year 2000, there was no remarkable activity regarding egovernment (Didraga and Brandas, 2014, 2015; European Commission, 2014; 2015a; 2015b; Stoica, 2009). Since 2000, the effectiveness of implementing egovernment projects in Romania is very much visible as a government strategy attempt to make more services available on the Internet as well as public information (Didraga and Brandas, 2014, 2015). The first step was made by the publication of Law no. 544/2001, on Free Access to Information of Public Interest, and in March 2002 the Romanian eProcurement system, 'www.e-licitatie.ro' was launched. A big step forward was in September 2003, when the Government launched the e-government portal, 'www.e-guvernare.ro' (European Commission, 2015b; Didraga and Brandas, 2014).

Romanian e-government strategies (European Commission, 2015b):

- The National Action Plan e-Administration - in October 2001;

- the Ministry of Public Finance's IT Strategy document for 2003-2006 in March 2003;

- Government Programme 2004-2008, which included an 'eGovernment Programme' and a 'Policy in the field of information technology and communications' sections;

- ASSI ('e-guvernare') Strategy in November 2008, stopped in 2009;

- Government Programme 2009-2013 ('eRomania');

- National Programme for Supercomputing (2010-present);

- National Strategy on Digital Agenda for Romania 2014-2020.

Considering the development of e-government services, the United Nations performed several surveys and in the most recent (United Nations, 2014), Romania is ranked as a high-EGDI (between 0.5 and 0.75 ) country worldwide with and 
EGDI value of 0.56315. Otherwise, among the EU countries, Romania is one of the low-ranked countries regarding the e-government development index (Didraga and Brandas, 2014, 2015).

In Romania, only 5\% of citizens have used e-government services in 2013 (MCSI, 2015), and the assumed target of 35\% must be reached by the end of 2020 .

\subsection{From e-government to e-government 2.0}

E-government 2.0 is "the next generation of e-government". Traditional egovernment is focused on technological changes, but e-government 2.0 is focused on "citizens as not only users but active contributors to e-government" (Meijer et al., 2012). Governments need to transform themselves into adaptive organizations and respond to the needs of citizens. They must discover new ways to fulfill their mission. In this respect, Web 2.0 is very important and useful for e-government 2.0 (Sun et al., 2015). Boughzala et al. (2015) consider that e-government has become slowly more social-based and open, allowing the development of the new egovernment generation, called e-government 2.0, with the emergence of Web 2.0 technologies and the ascent of social networks. Government 2.0 is a government that uses Web 2.0 (Meijer et al., 2012).

The fundamental characteristics of e-government 2.0 or gov 2.0 are (Boughzala et al., 2015):

- it is community-driven: social interactions between equal stakeholders;

- user-generated content and development: citizens and businesses become more involved in providing ideas, suggestions, and improvements;

- openness: data is open to public, transparent and can be used for innovation;

- collaboration: citizens and government create content and interact with each other.

E-government 2.0 involves extending the limits of government by inviting stakeholders to participate in government (initiating new services, making suggestions, and having access to governmental data) (Sun et al., 2015).

The maturity of the e-government system influences the quality of the services delivered and the satisfaction of citizens and other stakeholders (Khalil, 2011).

In Gov 2.0, users can give feedback of their satisfaction with e-government services, and they can influence the government actions in the future (Sun et al., 2015).

Gov 2.0 integrates Web 2.0 technologies, thus creating the opportunities to enhance the quality of online public services and changing the way citizens and businesses relate to the public administration (Boughzala et al., 2015). Web 2.0 is the "fuel for e-government 2.0" (Sun et al., 2015).

In Georgescu and Popescul (2014) opinion, Web 2.0 represents "the change brought on the Internet by a sum of social, economical, technological tendencies 
Didraga, O., (2015)

Risk management in future romanian e-government 2.0 projects

which have transformed and keep on transforming it into a distinctive environment, of great impact, characterized by the participation of the users, its openness and the network effects".

Tesu (2012) considers that the users of online services seek the closest way to make use efficiently of available Web 2.0 tools for a value-added experience.

Bonson et al. (2012) and Dixon (2010) classify Web 2.0 technologies, platforms and tools used in gov 2.0 as in Table 1.

Table 1. Technologies and platforms for e-government 2.0

\begin{tabular}{|c|l|}
\hline Web 2.0 & - Content syndication (RSS, Atom and vodcasting-podcasting); \\
technologies & - Widgets; \\
& - Sharing and bookmarking facilities; \\
& - Mashups. \\
\hline $\begin{array}{c}\text { Other additional } \\
\text { technologies }\end{array}$ & - Embeddings; \\
\hline - Webcasts. \\
\hline $\begin{array}{c}\text { Social media } \\
\text { platforms }\end{array}$ & - Blogs and micro-blogs; \\
& - Wikis; \\
\hline
\end{tabular}

Source: adapted from Bonson et al. (2012) and Dixon (2010)

There is a need for the public sector to invest in a greater adoption, use and evaluation of web 2.0 technologies by the population regarding e-services (Dixon, 2010).

Sun et al. (2015) list the challenges for transitioning to e-government 2.0:

- E-literacy and digital divide;

- Sustainability and cost structures;

- Privacy, security, and trust;

- Permanent availability and preservation;

- Education, marketing and workforce issues;

- Benchmarking, law and public policy;

- Transparency and accessibility;

- Content management (CM);

- Interoperability;

- Infrastructure development.

2.3 E-government 2.0 issues, risks and challenges for successful projects Gov 2.0 is a version of e-government more open and more user-centered (Meijer et al., 2012). One of the challenges of gov 2.0 is to transform the relationship between 
its stakeholders (citizens, businesses and government) through cooperation (Meijer et al., 2012).

Gov 2.0 issues and risks according to Boughzala et al. (2015):

- Security and hacking (theft, fraud, forgery, information leaks, etc.);

- Labor effort (work overload and unfulfilled requests);

- Network operating (fragile networks, out-of-bound changes);

- Sustaining the community (reinforcing citizen interest);

- Loss of control (too much transparency);

- New system and processes (government 2.0 facilitators);

- Institutional and organizational change;

- Intellectual rights (intelectual property);

- Personal data and privacy (lack of protection for private data and personal identity).

Savoldelli et al. (2014) conducted a study in which they found out some barriers to e-government adoption: technological and operational matters for the first years of e-government and institutional and political issues for the recent period.

The challenges for the realization of Gov 2.0 (Meijer et al., 2012) are transformational leadership, getting citizens interested and developing mutual trust. According to Khalil (2011), risk-avoiding behaviors are capable of supporting the thriving need for information of societies with high uncertainty practices. They develop sophisticated communication infrastructures, including e-Government interfaces through successful projects.

The key success factors for e-government projects are (Gatman, 2011):

- to be accessible (citizen and employee driven, many users, many web 2.0 channels);

- to be efficient (time and costs reduction);

- objective oriented (scalable, flexible, compatible, manageable, available);

- democratic (open, transparent, participatory);

- innovative (focused on information not on technology);

- safe and secure (security policies, security audits).

Meijer et al. (2012) consider that for successful Gov 2.0 applications, strong identity management through security policies is needed, but there are also downsides regarding privacy. The lack of protection for private data and personal identity is an important risk that diminishes citizens' trust, but reducing this risk, increases the trust (Colesca, 2009).

\section{Research methodology}

\subsection{Research problem}

The main problem is the proposal of a risk management plan for the e-government lines of action within the strategic lines of development from the Digital Agenda 
Didraga, O., (2015)

Risk management in future romanian e-government 2.0 projects

for Europe Strategy 2020.

\subsection{Research design}

A risk management plan proposal for the e-government lines of action within the strategic lines of development that includes identifying, assessing, and mitigating the risks. The research is theoretical, and it is based on existing literature.

\subsection{Research objectives}

The first steps of the risk management plan proposal are: to define risks, to rate risks by likelihood and consequence, and to classify risks by categories.

The next step is to code each specific risk and integrate it in the risk information categories.

The final step of the risk management plan is to integrate the risk identification (by risk code) and risk mitigation actions in the lines of action within the strategic lines of development for e-government 2.0 from the Digital Agenda for Europe Strategy 2020 published by the MCSI (2015).

\section{Results and discussion}

Risk is "the effect of uncertainty on objectives" (ISO, 2009). It is characterized by reference to an event's likelihood of occurring, and its impact or consequence(s).

Risk likelihood can be:

- (1) Remote: low chance of risk occurring;

- (2) Unlikely: small to medium chance for risk to occur;

- (3) Likely: medium chance of risk occurring;

- (4) Highly likely: high chance for risk to occur;

- (5) Nearly certain: very high chance of risk occurring.

Consequence rating can be:

- (1) Negligible: with insignificant impact on objectives;

- (2) Minor: minor effects that can be corrected with little effort;

- (3) Moderate: a few objectives are affected;

- (4) Major: important damage to project, budget and/or delivery of services;

- (5) Severe: serious and sustained damage in service delivery, budget, and reputation.

Risk rating is the magnitude of a risk, calculated by multiplying the likelihood and consequence (Victorian Government, 2010b), and it can be:

- low (between 1 and 4);

- medium (between 5 and 12);

- high (between 15 and 25).

Risk information is presented in four categories (Victorian Government, 2010a): 
Didraga, O., (2015)

Risk management in future romanian e-government 2.0 projects

- Information publication and management (IPM): risks related to the storing, secure management and publication of content for Gov 2.0 projects;

- Moderation (M): risks related to the publication of user-generated content and its management;

- Resourcing (R): risks related to allocating resources and staff in Gov 2.0 projects;

- Project management (PM): risks related to managing projects and measuring success.

The possible risk categories in e-government 2.0 projects are presented in Table 2, and the risks are coded by the sub-category they relate to.

Table 2. Risk categories in e-government 2.0 projects

\begin{tabular}{|c|c|c|}
\hline Risk sub-category & Specific risks & $\begin{array}{c}\text { Risk } \\
\text { information } \\
\text { category } \\
\end{array}$ \\
\hline \multirow{2}{*}{$\begin{array}{c}\text { Strategic } \\
\text { medium and long-term } \\
\text { sustainability risks } \\
\end{array}$} & ST01. Inappropriate choice of social media; & PM \\
\hline & ST02. Legal actions against the government. & IPM, M \\
\hline \multirow{8}{*}{$\begin{array}{l}\text { Reputation } \\
\text { risks damaging the } \\
\text { credibility perception } \\
\text { of stakeholders }\end{array}$} & R01. Legal liability (information with damaging consequences); & IPM, M \\
\hline & R02. Brand damage (key stakeholder perception); & $\mathrm{M}$ \\
\hline & $R 03$. Breach of publication rights (copyright infringement); & IPM \\
\hline & R04. Breach of implicit trust (decisions contrary to public feedback); & M \\
\hline & $R 05$. Breach of confidentiality (information privacy); & IPM \\
\hline & $\begin{array}{l}\text { R06. Information privacy scope (broader access and unintended uses } \\
\text { of published information); }\end{array}$ & IPM \\
\hline & R07. Information quality and integrity (inaccurate or superseded); & IPM \\
\hline & $\begin{array}{l}\text { R08. Loss of control of published information (cannot be deleted or } \\
\text { withdrawn). }\end{array}$ & IPM \\
\hline \multirow{2}{*}{$\begin{array}{c}\text { Cost } \\
\text { risks causing exceeds } \\
\text { of budget }\end{array}$} & $\begin{array}{l}\text { C01. Increased cost of service provision (due to additional } \\
\text { resourcing, additional tools, training, monitoring, auditing, etc.); }\end{array}$ & $\mathrm{R}$ \\
\hline & $\begin{array}{l}\text { C02. Cost of information provision (due to information formatting, } \\
\text { reviewing, approval, etc.). }\end{array}$ & $\mathrm{R}$ \\
\hline \multirow{2}{*}{$\begin{array}{l}\text { Target performance } \\
\text { risks causing objectives } \\
\text { not to be met }\end{array}$} & $\begin{array}{l}\text { T01. Diversion from primary objectives (diversion or loss of control } \\
\text { of resources, engaging low-priority problems, moderation, etc.); }\end{array}$ & PM \\
\hline & T02. Benefits realisation (lack of KPIs). & PM \\
\hline $\begin{array}{c}\text { Schedule } \\
\text { risks causing exceeds } \\
\text { of time }\end{array}$ & $\begin{array}{l}\text { SC01. Business impact of dependency (related or dependent } \\
\text { projects). }\end{array}$ & PM \\
\hline \multirow{2}{*}{$\begin{array}{c}\text { Fit for purpose } \\
\text { risks causing services } \\
\text { or projects not to } \\
\text { deliver stated aims }\end{array}$} & F01. Hijacking (gov 2.0 service hijacking by individuals or groups); & M \\
\hline & $\begin{array}{l}\text { F02. Authentication, identity and disclosure (compromising service } \\
\text { delivery by not determining the true identity of participants). }\end{array}$ & $\mathrm{M}$ \\
\hline
\end{tabular}

Source: adapted from Victorian Government (2010a, 2010b)

Table 3 presents the possible risk of Gov 2.0 and risk mitigation actions for projects that are developed within the future strategy and lines of action for Egovernment 2.0.

DE GRUYTER

OPEN 
Didraga, O., (2015)

Risk management in future romanian e-government 2.0 projects

Table 3. Strategic lines of development, corresponding lines of action for EGovernment 2.0, possible project risks and response measures

\begin{tabular}{|c|c|c|}
\hline \multicolumn{3}{|l|}{ Lines of Development } \\
\hline Lines of Actions & $\begin{array}{l}\text { Possible Gov } \\
\text { 2.0 Risks }\end{array}$ & Risk Mitigation \\
\hline \multicolumn{3}{|c|}{ 1. Provide better public services through the use of e-government 2.0} \\
\hline $\begin{array}{l}\text { Define the Informational Perimeter of } \\
\text { Public Services }\end{array}$ & - & Not applicable \\
\hline $\begin{array}{l}\text { Implement an institutional structure meant } \\
\text { to support the implementation of } \\
\text { eGovernment projects }\end{array}$ & - & Not applicable \\
\hline \multirow{3}{*}{$\begin{array}{l}\text { Promote better standards, transparency and } \\
\text { openness }\end{array}$} & R08 & - Content lifecycle management controls. \\
\hline & F01 & $\begin{array}{l}\text { - Awareness and monitoring of user } \\
\text { contributions and site usage. }\end{array}$ \\
\hline & F02 & $\begin{array}{l}\text { - Appropriate levels of authentication and } \\
\text { proof of user identity. }\end{array}$ \\
\hline \multirow{2}{*}{$\begin{array}{l}\text { Identification of data registries and } \\
\text { relevant owners of data registries for } \\
\text { interoperability }\end{array}$} & T01 & $\begin{array}{l}\text { - Prioritization, control policies, and } \\
\text { accurate estimation of resources. }\end{array}$ \\
\hline & $\mathrm{T} 02$ & $\begin{array}{l}\text { - Defining KPIs for successful projects. } \\
\text { - Ensuring the availability of tools for } \\
\text { measuring objectives. }\end{array}$ \\
\hline \multirow{8}{*}{ e-Participation } & $\mathrm{R} 03$ & $\begin{array}{l}\text { - Information security and publication } \\
\text { controls. }\end{array}$ \\
\hline & R04 & $\begin{array}{l}\text { - Request feedback for implemented } \\
\text { services. }\end{array}$ \\
\hline & R05 & - Information security controls. \\
\hline & $\mathrm{C} 01$ & \multirow{2}{*}{$\begin{array}{l}\text { - Accurate estimation of costs with } \\
\text { resources. }\end{array}$} \\
\hline & $\mathrm{C} 02$ & \\
\hline & SC01 & $\begin{array}{l}\text { - Accurate estimation of staff time } \\
\text { allocation and feedback timeframe. }\end{array}$ \\
\hline & F01 & $\begin{array}{l}\text { - Adequate monitoring of user } \\
\text { contributions. }\end{array}$ \\
\hline & F02 & $\begin{array}{l}\text { - Appropriate levels of authentication and } \\
\text { proof of user identity. }\end{array}$ \\
\hline \multirow{4}{*}{ Interoperability } & ST01 & $\begin{array}{l}\text { - Adequate preparation and research } \\
\text { regarding social media options }\end{array}$ \\
\hline & ST02 & $\begin{array}{l}\text { - Information security controls and } \\
\text { publishing appropriate content. }\end{array}$ \\
\hline & T01 & $\begin{array}{l}\text { - Prioritization, control policies, and } \\
\text { accurate estimation of resources. }\end{array}$ \\
\hline & T02 & $\begin{array}{l}\text { - Defining KPIs for successful projects. } \\
\text { - Ensuring the availability of tools for } \\
\text { measuring objectives. }\end{array}$ \\
\hline \multirow{2}{*}{ Improve legislation } & R01 & $\begin{array}{l}\text { - Information security and publication } \\
\text { controls. }\end{array}$ \\
\hline & $\mathrm{R} 02$ & $\begin{array}{l}\text { - Post-moderation of the service and } \\
\text { feedback }\end{array}$ \\
\hline \multicolumn{3}{|l|}{ 2. Increase the adoption of eGovernment services } \\
\hline $\begin{array}{l}\text { Consolidate institutional support and } \\
\text { oversight }\end{array}$ & - & Not applicable \\
\hline $\begin{array}{l}\text { Promote cooperation and collaboration } \\
\text { with public and private entities }\end{array}$ & R03 & $\begin{array}{l}\text { - Information security and publication } \\
\text { controls. }\end{array}$ \\
\hline
\end{tabular}

DE GRUYTER OPEN
Studia Universitatis "Vasile Goldis" Arad. Economics Series Vol 25 Issue 3/2015 ISSN 1584-2339. Web: publicatii.uvvg.ro/index.php/studiaeconomia. Pages $11-22$ 
Didraga, O., (2015)

Risk management in future romanian e-government 2.0 projects

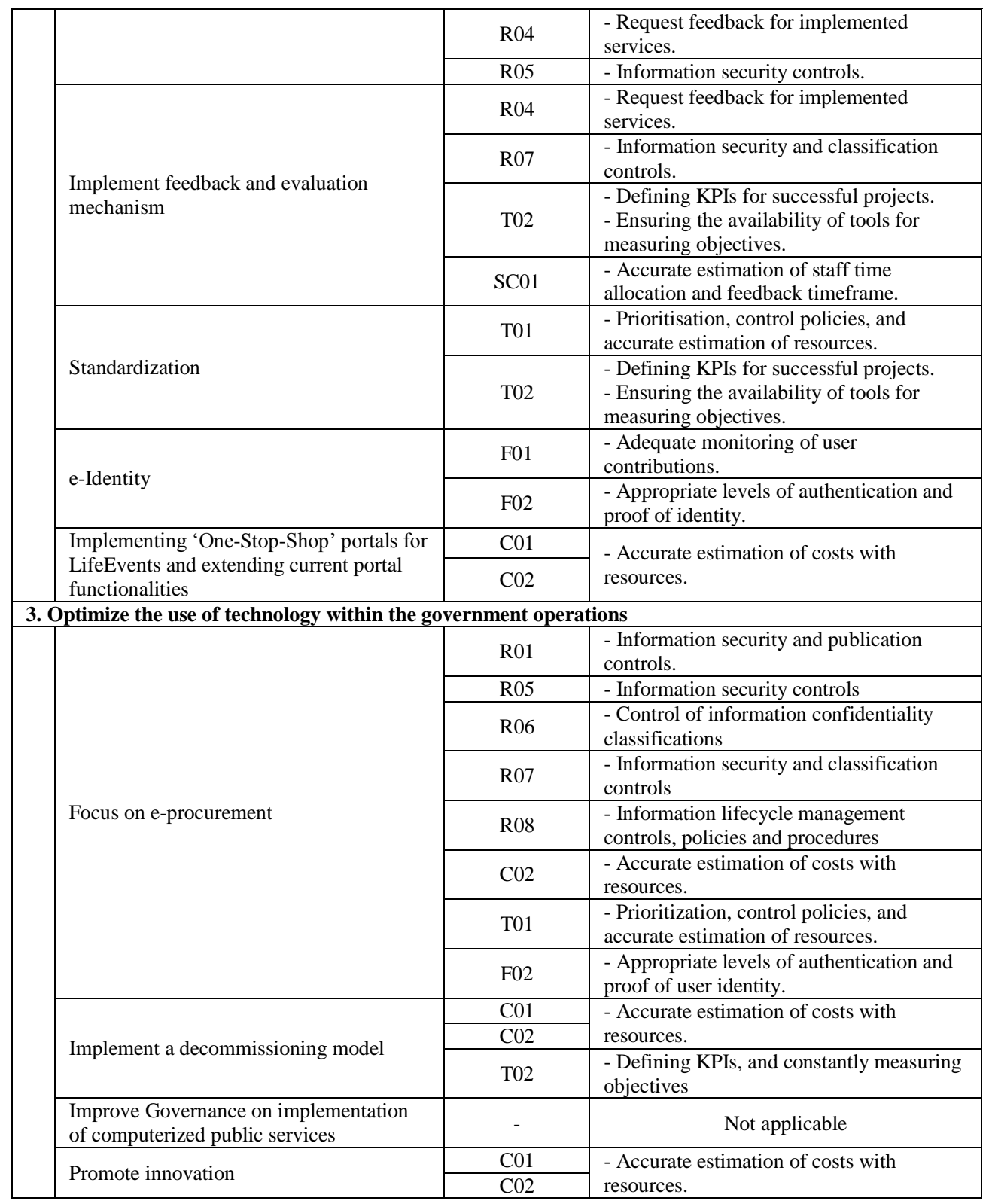

Source: self-processing from MCSI (2015) and Victorian Government (2010a, 2010b)

DE GRUYTER OPEN 
Didraga, O., (2015)

Risk management in future romanian e-government 2.0 projects

\section{Conclusion}

The National Strategy on Digital Agenda for Romania includes a field of action regarding e-government. All the future e-government 2.0 projects must comply with the strategic lines of development and fit the lines of action in the National Strategy.

E-government in Romania has evolved from the first small steps in the early 2000 's to the all-new concept of e-government 2.0 that encapsulates Web 2.0 technologies.

E-government 2.0 has to be implemented because of the cultural and behavioral transformations in the interaction between governments and users of e-services. Egovernment 2.0 projects use tools and techniques of social media to accomplish their goals. Gov 2.0 is community-driven, its content is user-generated and developed, it is open to public and it is based on collaboration, providing better services and meeting more user demands.

This involves that the projects that implement new services must consider risk management (identification, assessment and mitigation) as a mandatory activity to manage the risks and issues (strategic, reputation, cost, target, schedule, and purpose).

The article proposed a risk management plan for the future projects that must be aligned with the strategic lines of development: provide better public services through the use of e-government 2.0, increase the adoption of eGovernment services, and optimize the use of technology within the government operations.

New and modernized government services through e-government 2.0 projects that apply risk management will bring a significant improvement in how citizens and businesses relate to government and will increase the use of e-government services.

\section{Acknowledgement}

This work was cofinanced from the European Social Fund through Sectoral Operational Programme Human Resources Development 2007-2013, project number POSDRU 159/1.5/S/142115 "Performance and excellence in doctoral and postdoctoral research in Romanian economics science domain".

\section{References}

1. Bannister, F., \& Connolly, R. (2015). The great theory hunt: Does e-government really have a problem?, Government Information Quarterly, 32, 1-11.

2. Bonsón, E., Torres, L., Royo, S., \& Flores, F. (2012). Local e-government 2.0: Social media and corporate transparency in municipalities, Government Information Quarterly, 29, 123-132.

3. Boughzala, I., Janssen, M., Assar, S. (2015). E-Government 2.0: Back to Reality, a 2.0 Application to Vet (Chapter 1), In I. Boughzala, M. Janssen, Assar S. (Ed.), 
Case Studies in e-Government 2.0 - Changing Citizen Relationships (pp. 1-14), Online: Springer International Publishing Switzerland, ISBN 978-3-319-08081-9 (eBook).

4. Colesca, S.E. (2009). Increasing E-Trust: A Solution to Minimize Risk in EGovernment Adoption, Journal of Applied Quantitative Methods, 4(1), 31-44.

5. Didraga, O., \& Brandas, C. (2014). Study on the E-Government State of Play in Romania, Proceedings of the Multidisciplinary Academic Conference on Economics, Management and Marketing (MAC-EMM 2014), December 5-6, 2014, Prague, Czech Republic.

6. Didraga, O., \& Brandas, C. (2015). Comparative Study on E-Government Indicators between Romania and the European Union, Informatica Economica Journal, 19(1), 67-76.

7. Dixon, B. (2010). Towards E-Government 2.0: An Assessment of Where EGovernment 2.0 is and Where It Is Headed, Public Administration \& Management, 15(2), 418-454.

8. European Commission (2014). Delivering the European Advantage? 'How European Governments can and should benefit from innovative public services' eGovernment Benchmark - May 2014, Luxembourg: Publications Office of the European Union, ISBN 978-92-79-38052-5.

9. European Commission (2015a), Digital Agenda Scoreboard 2014 - Romania, Retrieved from http://ec.europa.eu/digital-agenda/en/scoreboard/romania Accessed 18 March 2015.

10. European Commission (2015b), eGovernment in Romania, Edition 12.0 eGovernement Factsheets, January 2015, Retrieved from https://joinup.ec.europa.eu/sites/default/files/egov_in_romania_-_january_2015_v.12.0 final.pdf Accessed 21 March 2015.

11. Gatman, A. (2011). e-Government - Assisting Reformed Public Administration in Romania, Romanian Journal of Economics, 32, 1(41), 216-242.

12. Georgescu, M., \& Popescul, D. (2014). The uncertainty of using Web 2.0 Technologies in E-Government development. Romania's Case, Procedia Economics and Finance, 15, 769-776.

13. ISO (2009). ISO 31000:2009. Risk management - Principles and guidelines, Switzerland: International Organization for Standardization.

14. Khalil, O.E.M. (2011). E-Government Readiness: Does national culture matter?, Government Information Quarterly, 28, 388-399.

15. MCSI (2015). Strategia Națională privind Agenda Digitală pentru România 2020 - Februarie 2015, Retreieved from http://www.mcsi.ro/CMSPages/GetFile. aspx ?nodeguid=0617c1d7-182f-44c0-a978-4d8653e2c31d Accessed 10 April 2015 
Didraga, O., (2015)

Risk management in future romanian e-government 2.0 projects

16. Meijer, A.J., Koops, B.-J., Pieterson, W., Overman, S., \& ten Tije, S. (2012). Government 2.0: Key Challenges to Its Realization, Electronic Journal of EGovernment, 10(1), 59-69.

17. Savoldelli, A., Codagnone, C., \& Misuraca, G. (2014). Understanding the egovernment paradox: Learning from literature and practice on barriers to adoption, Government Information Quarterly, 31, S63-S71.

18. Stoica, O. (2009). E-Government Implementation in Romania. From National Success to International Example, Retrieved from http://www.nispa.org/ conf_paper_detail.php?cid=17\&p=1549\&pid=166, Accessed 21 March 2015.

19. Sun, P.-L., Ku, C.-Y., \& Shih, D.-H. (2015). An implementation framework for E-Government 2.0, Telematics and Informatics, 32, 504-520.

20. Tesu, M.D. (2012). Developing E-Government for Better Public Services Within European Union, Theoretical and Empirical Researches in Urban Management, 7(2), 79-88.

21. United Nations (2014). E-Government Survey 2014 - E-Government for the Future We Want, New York: United Nations, ISBN: 978-92-1-123198-4, available online: http://www.unpan.org/e-government.

22. Victorian Government - Department of Premier and Cabinet (2010a). Government 2.0 Projects in VPS: an introduction to managing risk, Retrieved from http://www.vic.gov.au/blog/social-media-guides/government-2-0-projects-vpsintroduction-managing-risk/ Accessed 20 April 2015.

23. Victorian Government - Department of Premier and Cabinet (2010b). Victorian Public Service - Government 2.0 Risk Register and Management Plan, Retrieved from http://www.vic.gov.au/blog/social-media-guides/victorian-public-servicegovernment-2-0-risk-register-management-plan/ Accessed 20 April 2015. 